\title{
A Study on the Teaching Reform of College Business English Extended Course Based on CBI
}

\author{
Tiannan Zhou* \\ School of Foreign Languages \\ Northeast Petroleum University \\ Daqing, Heilongjiang, China
}

\author{
Dapeng Zhang \\ Business English Department \\ Harbin Finance University \\ Harbin, Heilongjiang, China
}

\author{
Xiaojuan Yao \\ School of Foreign Languages \\ Northeast Petroleum University \\ Daqing, Heilongjiang, China
}

\begin{abstract}
The study aims to discuss the application of content-based instruction (CBI) in teaching College Business English Extended Course, which is open to non-English majors, and students' English level is relatively poor. The traditional College Business English Extended Course tends to focus on the cultivation of students' language skills, while ignoring the teaching of business content; therefore, it can't meet students' needs for business knowledge. CBI teaching can better integrate English with business, so it not only helps to promote students' interest in learning, but also greatly improves the teaching effect of Business English.
\end{abstract}

Keywords-CBI; Business English; Extended Course; Teaching Reform

\section{INTRODUCTION}

With the rapid increase of global economic and trade activities and the implementation of the Belt and Road Initiative, international exchanges are becoming more frequent. Therefore, in order to adapt to the development of social economy, our country urgently need a large number of highquality compound talents. On the other hand, the popularization of higher education in China in recent years has made it possible to educate the public social knowledge and professional ability. The reform of College English teaching has been constantly deepened and extensively developed a variety of "English $+X$ " extended course mode for the sake of meeting the needs of talent development in the new century and the needs of different learners. College Business English Extended Course emerged in this context. Business English was gradually developed on the basis of technical English in the second half of the 20th century. It belongs to the category of English for special purposes (ESP). Some researchers believe that business English learning is not suitable for

This article is one of the research results of the project in 2018 The study on Teaching Mode of College Business English Extended Course under CBI Concept (WY2018034-B) sponsored by Key Research Projects on Economic and Social Development of Heilongjiang Province, the project in 2017 The Study on Ethical Literary Criticism of The Lost Generation in America (17WWB065) sponsored by Philosophical and Social Science Program of Heilongjiang Province, and the project in 2018 “A Study on the Public Sign Translation of Heilongjiang Tourist Attractions under the Functional Language Theory" (2018-KYYWF-022) sponsored by College Basic Research Funding Project of Harbin Finance University. students with lower English proficiency, and intermediate to advanced foreign language levels are required to achieve good results and performance. Therefore, College Business English Extended Course is mainly for sophomore students who have passed the College English Test Band 4. These students are not as good at English as English majors, and their business knowledge is also very limited. Hence in order to cultivate high-quality composite business English talents, teachers need to effectively integrate the business knowledge and language skill, explore practical and efficient teaching models.

\section{ANALYSIS OF THE CHARACTERISTICS AND SITUATION OF BUSINESS ENGLISH EXTENDED COURSE}

Business English Extended Course for non-English majors is generally taught by public English teachers with a major in English language and literature and little business knowledge. Therefore, they tend to teach traditional language skills such as listening, speaking, reading and writing, while ignoring business content. The characteristics of "English + business" in Business English Course can't be fully reflected, so that students can't meet the thirst for business knowledge, and can't stimulate students' interest in learning. As far as students are concerned, due to the strong professionalism of business English, formal language, tedious content, and deviation from daily life, it is difficult for students to maintain their interest in learning. Coupled with lack of self-confidence to their oral English and dependence on traditional infusion teaching, most students are less motivated in class participation, and teaching activities for teachers are difficult to carry out. In view of the characteristics of the Business English Extended Course and the situation of students, teachers should actively adjust and reform the teaching mode. In order to stimulate students' interest in learning and participation, to achieve a better teaching effect, to cultivate more qualified English business talents, teachers should not only pay attention to the improvement of students' language ability, but also to the development of students' business knowledge, business skills and cross-cultural awareness. 


\section{ESTABLISH BUSINESS ENGLISH TEACHING OBJECTIVES}

The goal of teaching can improve the efficiency of teaching, and "it can greatly stimulate students' motivation and initiative in learning English.” [1] Business English Extended Course aims to cultivate the professional applied foreign-related talents, and lay a good foundation for students working in English in future jobs, and at the same time, it will enable them to successfully acquire knowledge in relevant fields in the next few years and prepare for further study. Therefore, "the purpose of business English teaching is not to simply impart language knowledge, but to focus on language practice and communication skills training, that is, to develop the ability of learners to use business skills to accomplish business tasks in a more realistic business environment while learning basic business language and business knowledge.” [2] Specifically, the teaching objectives of the Business English Extended Course should focus on three aspects: (1) the cultivation of language communication skills. Develop students' ability to understand and use English properly in a business environment (2) acquire business expertise. Learn about business knowledge, familiarize yourself with the main business language and scenarios by learning practical materials about business activities. (3) cross-cultural communication and improvement of humanistic literacy. In specific business activities, the two sides of the communication must understand each other's culture, customs, habits and other social factors, so the teaching goal mainly focuses on general education such as Eastern and Western literature and culture, and improves students' sensitivity to cultural differences.

\section{INTEGRATE CBI TEACHING CONCEPT INTO BUSINESS ENGLISH TEACHING}

\section{A. An Introduction to the CBI Teaching Concept}

The Content-Based Instruction (CBI) "derived from the Immersion Program of St. Lanbert in Montreal, Canada in the 1960s, which was originally applied in kindergartens to teach English-speaking children to learn French.” [3] It is a concept of foreign language teaching based on a certain theme or a subject. The theoretical basis of the CBI teaching is cognitive science and second language acquisition theory. "Cognitive science shows that the intellectual activities that human beings engage in are all based on the combination of process and content."[4] Therefore, the learning of the second language also needs to combine the language skills and the knowledge content in the learning process to ensure the effective operation of the logical thinking process such as listening, speaking, reading and writing. Krashen's second-language acquisition theory also points out that "the best method of second language acquisition is to let learners be in a good, native-like learning environment, and language acquisition should focus on meaningful, understandable input rather than language form." [5]

CBI theory stands out from the traditional language teaching methods by "guiding the study of language to the study of subject. Language is no longer a learning goal, but a carrier for learning subject.” [6] Nowadays, CBI concept has been increasingly favored in foreign language teaching around the world. "This teaching concept is to make students become independent learners and continue to learn out of class.” [7] In many English teaching, "business English especially reflects the interdisciplinary attributes, which aims to cultivate

'English + X' (X refers to a business professional content) compound talents". [8] Therefore, the CBI teaching is undoubtedly the best choice for business English development. Through content teaching, students' motivation for learning is enhanced, and interest in learning is stimulated, and they improve their language level naturally while using English as a tool to acquire business knowledge.

\section{B. Reasonable Choice of CBI Teaching Method}

Brinton et al. define CBI as a combination of specific content and language teaching objectives. "Leaver \&Stryker propose that CBI is a teaching method that enhances language skills through content knowledge rather than language itself. Short believes that teachers who implement CBI use topics and content rather than grammar rules and vocabulary learning as the basis for teaching. " [9] Although CBI teaching model is a pedagogy that combines language and content, the difference in the ratio of language to content can produce multiple modes of operation. Each mode has its own specific theoretical principles and practical operating rules, which embodies the respective proportions of the language and content in the teaching under the premise of mutual integration. Met divides it into five modes: (1) total and partial immersion, (2) sheltered classes, (3) subject course plus language instruction, (4) themebased classes, and (5) content for practice. The content of these five modes is gradually decreasing, and the proportion of language is gradually increasing. This shows that the CBI model should be categorized on a case-by-case basis, and they play different roles in our foreign language teaching. In business English teaching, the choice of CBI mode should distinguish two concepts first, namely English for General Business Purposes (EGBP) and English for Specific Business Purposes (ESBP). EGBP is a junior business English model with low cognitive difficulty. Business knowledge plays the role of language carrier, and the teaching focus is on traditional listening, speaking, reading and writing training. EGBP belongs to the advanced business English model, in which both business knowledge and language skills are equally important, or master the business content, supplemented by language learning. The distinction between these two concepts makes us quickly discover the theme-based model of CBI is the best choice for College Business English Extended Course. The theme mode can select typical business theme, case, and scenarios according to teaching requirements and students' interests. At the same time, through the well-designed game and exercises, students' interest in learning can be stimulated to meet their desire for business knowledge and language skills.

\section{Careful Design of CBI Teaching Content}

We can't simply regard business English as a language variant, nor a simple addition of English and business, but a communication system with English language as the carrier, business activities as the content, and business communication as the purpose. The cultivation of knowledge and abilities of Business English Extended Course can be divided into four parts, language skills, business knowledge, intercultural 
communication ability and humanistic quality. Therefore, the design of the teaching content should fully consider these four aspects, so that students' comprehensive business English ability and quality are improved. First of all, for students who are just getting started in business English, teachers can choose primary business English textbooks with less professionalism and rich subject matter. Each unit of the textbook is a relatively independent business module that enables students to understand the various topics of business English. There are different ways to organize the content of the instruction. One way is to take a step-by-step approach, such as teaching simple words, grammar, sentence patterns, and then complex ones, or practicing scenes that students are familiar with in their daily life, such as business phone role play, and then learn to simulate business meetings and other scenarios. The second method is to arrange the content according to the strength of the demand. In the light of the class schedule and learners' needs, teachers can teach important content first, such as job interviews, resumes and so on.

"Because business English is closely linked to real life, the use of complementary materials in teaching is especially important." [10] Supplementary materials have a variety of forms. Materials commonly used for teaching are in text form, such as letter, meeting minutes, email, contracts, etc., as well as corporate video recordings, video conversations, TV commercials and other audio and video materials. In addition, teachers should also display their language and literature expertise, collect literary and cultural materials, and integrate them into the business English course by reading key paragraph, literary reviews, and appreciation of the film and television clips. For example, in the film The Pursuit of Happiness, Gardner, a salesman, worked hard to become a well-known financial investor. In Gone with the Wind, Margaret Mitchell depicted Scarlett, a woman, was forced to do business to make a living after the outbreak of the Civil War, while the businesswoman in Atlanta was unprecedented at the time. The Last Tycoon of Fitzgerald portrayed a business genius Starr who promoted the development of Hollywood's film industry, and fell into various intrigues for power and profit at last. In The Great Gatsby, Gatsby run illegal business to accumulate wealth in pursuit of the golden girl Daisy, and eventually died tragically. In Hemingway's To Have and Have Not, in order to make money, Morgan did anything for money and finally died....These materials, full of values and ethics, stimulate students' interest in learning, while subtly improving their English skills and cross-cultural knowledge and humanistic quality.

In practice, the CBI model requires teachers to teach in a language appropriate to students' language level. Teachers should clearly explain classroom tasks; use rich multimedia and other auxiliary teaching methods to help students understand the concept of the subject, and closely link the new content and new concepts with the existing knowledge and experience of students in order to stimulate their motivation. After determining the theme, teachers should devise various activities and exercises to make students understand and master the business knowledge and language skills quickly by listening, speaking, reading, writing and translating. Constant practice of language is essential to maintaining the learners' second language level, so the CBI model encourages the active participation of students in classroom interactions around subject content, which will help students to understand the text and practice oral English, enhance learning interests, reduce the emotional barrier, avoid distractions, stimulate brain development, and so on. In general, textual materials can be dealt with reading practice first, and students can acquire business knowledge through reading. Teachers can also select main content from it, let the students translate and discuss the core issues in a group, and then let them practice writing around the knowledge they have learned. Voice and video materials can be used for communication skills, language, grammar and culture learning, as well as dictation exercises and communication strategy learning. For example, teachers can use a conference recording as a material to choose the vocabulary, syntax and communication skills from it, and then let the students perform role-playing, so that their English, business and teamwork skills can be improved. During the teaching process, teachers can also design some interesting small games to cultivate students' interest, such as connect English words, crossword puzzles and other vocabulary practice games, or let several students perform weird national customs and then let others guess which country they are from after teaching business etiquette and cross-cultural knowledge. Various practice and games increase the fun of teaching and learning, and teachers fully integrate theoretical teaching with skill teaching.

\section{Dynamic Evaluation of CBI Teaching Effects}

The teaching philosophy of CBI emphasizes that students are the main body, paying attention to the personal experience of students and the cultivation of students' overall language skills. Therefore, teaching evaluation has a certain guiding role. The evaluation of the effectiveness of business English teaching under the CBI concept should begin with teachers. As far as teachers are concerned, business English teachers should have solid language skills and be able to teach in bilingual or full English, and should also be proficient in business expertise, which put higher requirements to teachers. Therefore, teachers need to have the consciousness of self-development, establish the ambition of lifelong learning, and actively transform themselves from a common language teacher to a compound language teacher. Only in this way can teachers have more confidence to control the class and achieve good teaching effects. Assessment of students should be based on a combination of summative assessments and formative assessments. Teachers need to understand how much language knowledge students acquire through learning, as well as their ability to use Business English to solve practical problems in specific contexts. In addition to objective test scores, subjective assessment of students requires teacher's careful observation of students' situation. Therefore, students' learning process, classroom performance, task practice and other aspects should be included in the evaluation system. During the discussion and practical tasks of group activities, students have a positive social role and have acquired a large amount of language and knowledge information in the process of interaction with classmates, therefore, mutual evaluation among students is feasible. At the same time, students can also objectively evaluate their own learning situation before and after class by 
means of questionnaires. Finally, teachers also need to let students evaluate the degree of satisfaction with the course in order to provide useful inspiration for deepening the reform of college business English teaching.

\section{CONCLUSION}

In view of the characteristics of College Business English Extended Course, teachers' level and students' situation, the teaching method based on CBI can effectively utilize existing resources, maximize the integration and promotion of business knowledge and language teaching, and overcome the disadvantages of ignoring content in traditional teaching. At the beginning of teaching, the author finds that students do need a process of adjustment and lack of enthusiasm for participating activities. Some students are even resistant to this teaching model which requires a high concentration of students' attention and frequent participation. As the course progresses, students keep acquiring knowledge, and gradually get into learning under the influence of teachers and students around them. They are interested in the rich and fresh teaching activities and participate actively, becoming proactive language learners. The practice has proved that the content-based business English teaching model gives inspiration to integrate English with business knowledge to meet students' needs for language skills and future career development, conforms to the law of language learning, enhances students' learning motivation, and will become the main direction of second language research and teaching.

\section{REFERENCES}

[1] Cai Jigang, "Branched English Teaching under the Framework of CBI Theory”, Foreign Language Education, pp. 35-38, September, 2011. (In Chinese)

[2] Yin Xinzhe, Li Jinghua, "The Application and Assessment of Narrative Approach in Business English Teaching”, Foreign Language and Literature, pp. 142-147, June, 2012. (In Chinese)

[3] Ming Hong, “Content-based Instruction Concept and Business English Teaching”, Journal of Changchun University, pp. 1466-1472, October, 2014. (In Chinese)

[4] Chen Xi, "An Analysis of the Effectiveness of the Integration of CBI Teaching Concept into Business English Teaching”, Journal of Liaoning Radio TV University, pp. 16-17, February, 2017. (In Chinese)

[5] Ma Qing, “Application of CBI Teaching Model in College Business English Teaching”, Journal of Yangtze University, pp. 79-81, December, 2014. (In Chinese)

[6] Li Xiaoxu, "Practical Exploration of CBI Teaching in Business English Teaching”, Journal of Huanggang Normal University, pp. 32-35, February, 2018. (In Chinese)

[7] Gao Zhiguo, Wang Yaping, "CBI and Its Implications for the Teaching of Business Reading and Business Writing”, Journal of Gansu Lianhe University (Social Sciences), pp. 108-111, July, 2013. (In Chinese)

[8] $\mathrm{Li} \mathrm{Li}$, "A Study on Effects of Applying CBI to Business English Teaching”, Journal of Beijing International Studies University, pp. 74-79, August, 2010. (In Chinese)

[9] Wang Wei, “Adaptive Content in CBI for Business English Teaching in Chinese Universities Based on Needs Analysis”, Journal Beijing University of Chemical Technology (Social Sciences Edition), pp. 73-77, March, 2014. (In Chinese)

[10] Xia Lu, “Instructional Design of Business English”, Wu Han: Huazhong University of Science \& Technology Press, 2016, p. 19. (In Chinese) 